\title{
An Elderly Philadelphia Chromosome Positive Acute Lymphoblastic Leukemia Case Developed After 3 years of Post-chemotherapy
}

\section{Kemoradyoterapiden 3 Yıl Sonra Gelişen İleri Yaşlı Philadelphia Kromozomu Pozitif Bir Akut Lenfoblastik Lösemi Olgusu}

\author{
Özcan Saygılı, Bahar Uncu Ulu, Mehmet Bakırtaş, Dicle İskender, Mehmet Sinan Dal, Merih Kızıl Çakar, \\ Fevzi Altuntaş
}

Ankara Dr Abdurrahman Yurtaslan Onkoloji Eğitim Araştırma Hastanesi, Hematoloji

Dergiye Ulaşma Tarihi: 07.07.2019 Dergiye Kabul Tarihi: 11.11.2019 Doi: 10.5505/aot.2019.68736

\section{ÖZET}

Giriş: Tedavi ilişkili olarak da hematopoietik maligniteler gelişebilmektedir. Biz burada, mide kanseri nedeni ile kemoterapi ve radyoterapi alan bir olguda yaklaşık 3 yıl sonra gelişen bir akut lenfoblastik lösemi olgusunu bildirdik.

Olgu: Bilinen mide adenokarsinom tanısı olan hasta subtotal gasrektomi sonrasında radyoterapi ile eş zamanlı haftalık FUFA (5 Fluoro-urasil/leucoverin) tedavisi almış. Yaklaşık 3 yıl sonra lökositoz tespit edilen hastaya B hücreli akut lenfoblastik lösemi (B-ALL) tanısı koyuldu. Philedelphia kromozomu t(9;22) RT PCR ile pozitif saptand. Hasta 12 kür pomp idame + imatinib $600 \mathrm{mg}$ tedavisi verildi. Nüks olan hastaya dasatinib tedavisine geçildi.

Tartışma: Daha öncesinde kemoterapi almış olan hastalarda MDS ve AML haricinde ALL de gelişebileceği akılda tutulmalıdır.

Anahtar Kelimeler: akut lenfoblastik lösemi, sekonder, kemoterapi, radyoterapi

\begin{abstract}
Introduction: Hematopoietic malignancies may also develop in relation to treatment. Here, we report a case of acute lymphoblastic leukemia that developed in a patient who received chemotherapy and radiotherapy due to gastric cancer about 3 years later.

Case: A patient with known gastric adenocarcinoma received FUFA (5 Fluoro-uracil / leucoverin) weekly for simultaneous radiotherapy after subtotal gasrectomy. Leukocytosis was detected approximately 3 years later and B cell acute lymphoblastic leukemia (B-ALL) was diagnosed. The Philedelphia chromosome t $(9 ; 22)$ was positive with RT PCR. The patient was given 12 cycles of POMP maintenance + imatinib $600 \mathrm{mg}$. The patient who had relapse was started on dasatinib treatment.

Discussion: It should be kept in mind that patients with previous chemotherapy may develop ALL instead of MDS and AML.

Keywords: acute lymphoblastic leukemia, secondary, chemotherapy, radiotherapy
\end{abstract}

\section{GíRIŞ}

Akut lenfoblastik lösemi (ALL) sıklıkla çocukluk çağında görülür. ALL lenfoid öncül hücrelerin artışı ile karakterize agresif bir hastalıktır. İleri yaşta akut lenfoblastik lösemi hastalarında kemoterapi ile remisyonda olanlar1 idame kemoterapi ile izlenebilmektedir. Philedelhphia kromozomu pozitif olan ALL hastalarında ise tirozin kinaz inhibitörleri sağkalım artırıcı temel tedavilerdendir. Erişkin dönemdeki ALL hastalarında prognoz çocukluk dönemine göre daha kötüdür.

Tedavi ilişkili hematopoietik maligniteler arasında sekonder miyeloid lösemi ve sekonder miyelodisplaziler daha sik görülürken sekonder lenfoblastik lösemiler nadir olarak bildirilmektedir. 11q23 translokasyonları tedavi ile ilişkili akut lenfoblastik lösemi ( $t$-ALL) ile en çok ilişkilendirilen genetik bozukluklardır $(1,2)$. Bununla birlikte t-ALL ile en çok ilişkilendirilen ikinci genetik bozukluk 
t(9;22)'dir (3). Diğer yandan, 11q23 kromozom anomalileri siklıkla topoizomeraz inhibitörlerinden 2-3 yıl sonra görülen tedavi ilişkili akut miyeloid lösemi (t-AML) ile de ilişkilidir (4). Biz burada, mide kanseri nedeni ile kemoterapi ve radyoterapi alan bir olguda yaklaşık 3 yıl sonra gelişen bir akut lenfoblastik lösemi olgusunu bildirdik.

\section{OLGU}

79 yaşındaki bayan hasta halsizlik,genel vücut ağrıs1 ve ateş şikayetleri ile acil servise başvurdu. Anemi ve lökositoz bulguları saptanan hastanın periferik kan yaymasında \% 80 oranda orta büyüklükte dar ve bazofilik stoplazmaya sahip kromatin ağı gevşek blastlar görülmesi üzerine akut lösemi ön tanısı ile hematoloji servisine yatışı yapıldı. Hastaya Temmuz 2014'te evre 3c (t2n3am0) mide adenokarsinom tanisı konulmuş ve subtotal gastrektomi yapılmış. Ağustos 2014'te de radyoterapi ile eş zamanlı haftalık FUFA(5 Fluoro-urasil/leucoverin) kemoterapisi uygulanmış. Sonrasında hasta medikal onkoloji bölümünce remisyonda izlenmekteydi. Hastanın acil servis başvuru sonras1 laboratuar bulguları WBC: $35.700 / \mu 1$, hemoglobin:6,44 gr/dl, trombosit: $89.000 / \mu 1$, PMNL: $290 / \mu 1$ ve lenfosit: $13.800 / \mu 1$ idi. Akım sitometri analizinde CD19, CD 20, CD22, CD 10, TDT, CD79a sonuçları pozitif olarak gelirken; CD3, CD5,MPO, CD7 sonuçları negatif olarak geldi. Akım sitometri analizi sonucu B-ALL olarak değerlendirildi. Akım sitometri analizi sonucu B hücreli akut lenfoblastik lösemi(B-ALL) olarak geldi. Hastaya POMP kemoterapi protokolü başlanıldı. Philedelphia kromozomu $\mathrm{t}(9 ; 22)$ RT PCR ile pozitif gelen hastaya hastaya imatinib $600 \mathrm{mg}$ tablet tedavisi de başlanıldı.Kemik iliği biyopsi sonucunda da lenfoblastik infiltrasyon görülen hasta poliklinik takibine alındı (Figür1-2).

Hasta 12 kür pomp idame+ imatinib $600 \mathrm{mg}$ tb aldı. Sonrasında nüks olan hastaya vinkristin +prednol kt si verildi ve dasatinib $140 \mathrm{mg}$ tb $1 \mathrm{x} 1$ başlanıldı. Takiplerinde dasatinibe refrakter olan hastaya ponatinib tedavisine geçildi.Takiplerinde hasta febril nötropeni ile hospitalize edildi. Genel durumu kötüleşen hasta yoğun bakım servisine devredildikten sonra exitus oldu.

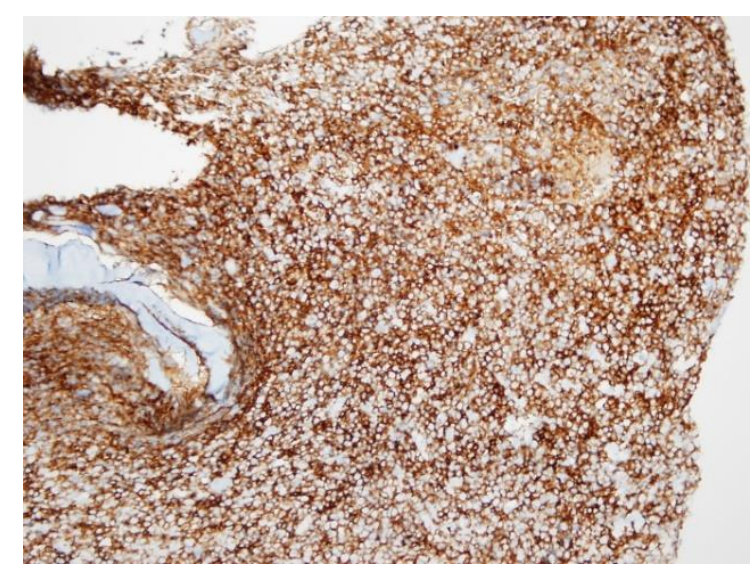

Figür 1. CD34 + Blastik hücreler.

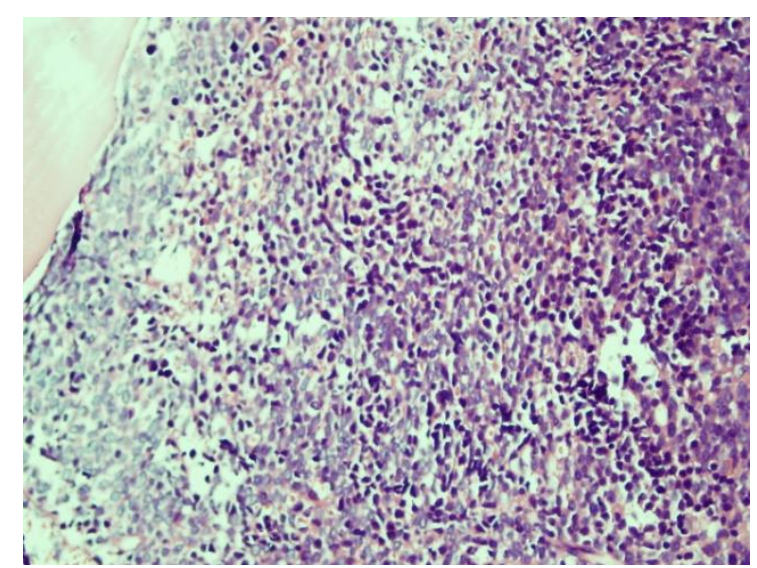

Figür 2. Blastik hücre infiltrasyonu

\section{TARTIŞMA}

Olgumuz mide kanseri sonrası gelişen bir akut lenfoblastik lösemi olgusu sunduk. Olgumuzda $\mathrm{t}(9 ; 22)$ translokasyonu da mevcuttu. Tedavi ile ilişkili AML tedavi ilişkili akut lösemiler arasında daha sık görülen form olması yanında bizim olgumuzda kemoradyoterapiden yaklaşık 3 y1l sonra ALL gelişmiştir. Tedavi ilişkili akut lenfoblastik lösemi nadirdir. Tedavi ilişkili ALL vakalarında en sık görülen sitogenetik değişiklik 11q23 kromozom anormalliğidir. Daha sonra ise $t(9 ; 22)$ ve normal kromozom karyotipi gelmektedir (2) . Hastada $\mathrm{t}(9 ; 22)$ pozitif olarak gelmesi de ALL'nin tedavi ilişkili mi yoksa de novo mu olduğu konusunda bilinmezliğe katkıda bulunabilmektedir. Ama hastanın radyoterapi de almış alması tedavi ilişkili olabileceğine dair ihtimali artırmaktadır. Genel olarak $\mathrm{Ph}+$ yaşlı ALL hastalarında tam remisyon oranının düşük, remisyon süresinin kısa ve tedavi ile ilişkili mortalitenin yüksek olması nedeni ile 
prognoz kötüdür. Kemoterapi alan ve nötropeni gelişen hastalarda gerek mantar enfeksiyonları gerek viral enfeksiyonlar ve diğer enfeksiyonlar s1k görülmektedir (5-7). $\mathrm{Bu}$ nedenle bu tip hastalarda nötropenik ateş açısından ve enfeksiyonlar açısından uygun ve hizlı tedaviler verilmelidir.

İmatinib'in yan etkisinin düşük olması nedeni ile yeni tanı konulan $\mathrm{Ph}+$ yaşlı tedavi ilişkili ALL hastalarında da imatinib düşük doz kemoterapi kombinasyonları ile kullanılabilir. Daha öncesinde kemoterapi almış olan hastalarda MDS ve AML haricinde ALL de gelişebileceği göz önünde bulundurulmalıdır.

Çıkar Çatışması Beyanı: Yazarlar çıkar çatışması olmadığını bildirmişlerdir.

Finansal Destek: Bu çalışma her hangi bir fon tarafından desteklenmemiștir.

\section{REFERANSLAR}

1. Andersen MK, Christiansen DH, Jensen BA, Ernst P, Hauge G, Pedersen-Bjergaard J. Therapy-related acute lymphoblastic leukaemia with MLL rearrangements following DNA topoisomerase II inhibitors, an increasing problem: report on two new cases and review of the literature since 1992. Br J Haematol 2001; 114: 539-543.

2. Chen W, Wang E, Lu Y et al. Therapy-related acute lymphoblastic leukemia without 11q23 abnormality: Report of six cases and a literature review. Am J Clin Pathol 2010; 133: 75-82.

3. Matnani $R$, Vishwas $P$, Borate $U$, Brazelton $J$, Reddy V, Peker D. Therapy-related Blymphoblastic leukemia associated with Philadelphia chromosome and MLL rearrangement: Single institution experience and the review of the literature. Pathology International 2015; 65: 536540

4. Pedersen-Bjergaard J, Philip P. Balanced translocations involving chromosome bands $11 \mathrm{q} 23$ and 21q22 are highly characteristic of myelodysplasia and leukemia following therapy with cytostatic agents targeting at DNAopoisomerase II. Blood. 1991;78:1147-1148.

5. Mert D, Batgi H, Merdin A, Çeken S, Dal MS, Tekgündüz E, Altuntaş F, Ertek M. BK virus-associated hemorrhagic cystitis in patients with allogeneic hematopoietic cell transplantation: report of three cases. Hematol Rep. 2017 Jun 26;9(2):7205. doi: 10.4081/hr.2017.7205. eCollection 2017 Jun 1.

6. Mert D, Iskender G, Duygu F, Merdin A, Dal MS, Doğan $M$, et al. Invasive aspergillosis with disseminated skin involvement in a patient with acute myeloid leukemia: a rare case. Hematol Rep. 2017 Jun 1;9(2):6997. doi: 10.4081/hr.2017.6997. eCollection 2017 Jun 1.

7. Yapici O, Gunseren F, Yapici H, Merdin A, Yaylali ÜÜ, Merdin FA. Evaluation of febrile neutropenic episodes in adult patients with solid tumors. Mol Clin Oncol. 2016 Mar;4(3):379-382. Epub 2015 Dec 28. 